\title{
Castration as Punishment for Rape in Kaduna State, Nigeria: Beaming Searchlight from Reproductive Health Right Perspective
}

\author{
OMIDOYIN, Taiye Joshua* \\ Senior Lecturer, College of Law, Achievers University, Owo, Ondo State, Nigeria \\ AWOSUSI, Bolade Damilola \\ Lecturer, Faculty of Law, Federal University, Oye-Ekiti, Ekiti State, Nigeria
}

\begin{abstract}
The increasing incidence of rape and sexual offences in Nigeria is not only alarming but disheartening. Several efforts have made by the federal government of Nigeria and various state governments to address the social menace, like opening sex offenders' register, practice of naming and shaming, imposing life sentences for convicted offenders, among other steps. In all these however, the heinous crime of rape and sexual offences have not been curtailed in the country, rather it is on the increase. Kaduna state government of Nigeria, in an attempt to tackle the crime, proceeded to amend the state's Penal Code and prescribed castration as appropriate punishment for convicted perpetrators of rape. As commendable as this may be, how effective can it serve as deterrence and does the punishment of castration fall within the goals of penology? More importantly, is castration tantamount to an abuse of reproductive health rights of the convict? These are the issues addressed in this article. The aim of this article is therefore to examine castration as punishment for the offence of rape from the perspective of criminal law and human rights. The findings of the research revealed that castration as punishment for the offence of rape in Kaduna state is a way too far, and may amount to retaliation rather than deterrence. The research concludes that cutting an aching head is not the solution to the headache, hence there are other ways to curb the rampant rape of rape than a punishment that violates reproductive health rights of the convict.
\end{abstract}

Keywords: punishment, castration, rape, perpetrators, reproductive health

DOI: $10.7176 / \mathrm{JLPG} / 110-01$

Publication date:June $30^{\text {th }} 2021$

\subsection{Introduction}

Rape is not only a condemnable crime but a gross violation of the right of the victim. No doubt, rape has become a pandemic that is spreading like wildfire in Nigeria, without the exclusion of any tribe, race or geopolitical zone. Rape hence becomes an act against both the individual and the state. Many states of the federation have been trying different measures to curb the rampant occurrence of rape, ranging from the naming and shaming practice, opening a sex offenders' register, creating more awareness for the people and so on. As much as the measures put in place to curtail the crime of rape are commendable, the prescribed punishment should also be humane, rational, justifiable and not conflicting with existing legislations or human rights standards. It is against this background that the Kaduna state law providing for castration as punishment for convicted rape offenders would be critiqued.

\subsection{The Essence of Criminal Punishment}

The law is generally enacted in furtherance of the duty of government in the social contract theory to create a balanced, peaceful and secured society. This duty of government likewise extends to making laws to curb societal wrongs and punish deterrent offenders. In the attempt to make provisions for punishment of offenders, the law seeks to achieve the goals of reparation, reformation, retribution and deterrence. ${ }^{1}$ The focal points of criminal punishment should therefore be tailored towards that and not to make it an instrument for persecution, retaliation, dehumanisation or flagrant stampede of the rights of offenders. While some purposes of punishment are aimed at benefiting society, others are just aimed at exacting revenge upon an individual who is responsible for the harm done. ${ }^{2}$ It however appears that some criminal punishments are imposed to inflict cruelty or malignant intentions, rather than having the future interest of the offender in mind. Another important angle to view criminal sentence is in the realm of compensation, hence a convict can be compelled to pay for his wrong to the society through physical labor, forfeiture of assets or restitution as the case may be. ${ }^{3}$

\footnotetext{
${ }^{1}$ Laws, 'Understanding the Purpose of Punishment' available on https://criminal.laws.com/general-criminal-law/purpose-of-punishment-overview accessed 27-03-2021

2 ibid

${ }^{3}$ ibid
} 


\subsection{Does Castration of Offenders fall within the goals of penology?}

As stated earlier, the cardinal goals of criminal punishment are reparation, reformation, retribution and deterrence. Castration has been prescribed as punishment for the offence of rape in Kaduna State, Nigeria. Do we say it falls within the purview of deterrence as purpose of criminal punishment? What is even castration and does it constitute infringement of human dignity? By way of definition, castration is any action, surgical, chemical, or otherwise, by which an individual loses use of the testicles: the male gonad. ${ }^{1}$ It is the excision of both testes of the male genital and apparently marked by the invasion of bodily autonomy, and intentionally causing bodily harm to an individual. ${ }^{2}$ Castration, especially of the male gender, is any action, either through surgical or chemical or through other means, by which a person loses his testicles: the male gonad. ${ }^{3}$ Castration could be orchiectomy or orchidectomy, and it can be done either through surgical excision of both testicles or the use of chemical or pharmaceutical drugs to deactivate the testes. ${ }^{4}$ The effect of castration is sterilization or drastic reduction in the production of certain hormones, such as testosterone.

The actual history or evolution of the practice of castration is not very clear but there is evidence that it was practiced as far back as 4,000BC based on what is described in the cult of Ishtar and Uruk. ${ }^{5}$ There is however the possibility that it arose during the Neolithic period when rising population was an issue to contend with. ${ }^{6}$ Meanwhile, castration was initially used in some cultures in Europe, South Asia, East Asia and Africa for religious ${ }^{7}$ or social reasons. ${ }^{8}$ The use of castration as punishment is not a recent practice, in fact it dates back to the $12^{\text {th }}$ century when Geoffrey of Anjou castrated the members of the cathedral chapter as Sens as punishment for disobedience. ${ }^{9}$ Also, in the same $12^{\text {th }}$ century during the medieval kingdom of Georgia, Demna was castrated by his uncle George III of Georgia to ensure the supremacy of George's branch of the family. ${ }^{10}$ Even in Medieval England, men found guilty of treason of a serious nature were hanged and their genitalia removed, a good example was William Wallace, the Scottish resistance leader, who was castrated as part of his execution in 1305 after he resisted English rule. ${ }^{11}$

The logic behind castration is not farfetched, because an individual has used his sexual organ to commit the offence of rape, such organ should be taken from him to avoid repeated occurrence. This practice is simply analogous to chopping off a person's hand as punishment for stealing. The question is, does castration align or violate human rights available to convicted offenders? Does castration fall within the circumference of lawful welfare of citizens (even after being convicted of a sexual offence)? The answers to these questions appear to be in the negative because castration as punishment for the offence of rape does not align with the objectives of penology and criminal punishment. It is likewise inhumane, painful, degrading and mutilating human body parts. More so, the philosophy of criminal punishment is gradually shifting from retributory justice to reformative justice, and this is for the purpose of reforming the convicts and reabsorbing them as bitter citizens in the society.

Chemical castration has been practiced in several countries of the world, including some states in the United States, South Korea, and Russia. South Korea became the first country in Asia to legalize castration penalties in 2011. ${ }^{12}$ Although nine states in United States of America, have implemented castration penalties, but the chemical used for castration has never been approved by FDA. Also in Russia, chemical castration has been used for child sex offenders, but the committers of this crime must be declared as a pedophile by a panel of doctors. ${ }^{13}$ But an appraisal of the practice of chemical castration in these countries revealed that it was used for therapeutic purpose, rehabilitation or treatment, or as a therapeutic attempt to perpetrate sexual offenses rather than as convictions. ${ }^{14}$

The implementation of chemical castration requires a total consent and agreement of the offenders, failure of which would be tantamount to violating international human rights law, ${ }^{15}$ particularly the right to resist

\footnotetext{
${ }_{1}^{1}$ NHS, 'Testicular Cancer-Treatment' available at www.nhs.uk/conditions/testicular-cancer/treatment/ accessed 27 February, 2021

2 ibid

${ }^{3}$ Kathryn Reusch, That Which Was Missing: The Archaeology of Castration (University of Oxford: PhD Thesis 2013)

${ }^{4}$ ibid

${ }^{5}$ Jean Wilson and Claus Roehrborn, 'Long-Term Consequences of Castration in Men: Lessons from the Skoptzy and the Eunuchs of the

Chinese and Ottoman Courts' (1999) 84(12) Journal of Clinical Endocrinology and Metabolism 4327

6 ibid

${ }^{7}$ Eunuchs were castrated to be admitted to a special social class to serve as bureaucrats and work in the palace.

${ }^{8}$ In ancient time, after wars, the victorious camps sometimes castrate their captives to symbolize victory, demoralize them and seize their power.

${ }^{9}$ Edward Gibbon, 'The History of the Decline and Fall of the Roman Empire' (27 April, 2020) Project Gutenberg

${ }^{10}$ Antony Eastmond, Royal Imagery in Medieval Georgia (University Park, Pennsylvania: Pennsylvania State University Press 1998 ) 107

${ }^{11}$ See John Bellamy, The Tudor Law of Treason (London: Routledge \& Kegan Paul 1979) pp202-204

${ }^{12}$ Kartono K. and Mulyana A. 'The Implementation of Chemical Castration Penalties towards Paedophilia Crime Perpetrators' (OctoberDecember 2019 ) Vol. 13(4) Jurnal Ilmu Hukum : Fiat Justisia, pp. 321-332

${ }^{13}$ Dina Silvia Puteri, Denita Cahyanti Wahono, Rr. Jannatul Firdaus, and Steven Sukamdani 'Chemical Castration from Criminal Law and Human Rights' (2020) 4(1) Jurnal Cepalo. Available at http://jurnal.fh.unila.ac.id/index.php/cepalo

${ }^{14}$ United Nations Country Team in Turkey (UNCT), White Paper Chemical Castration and Life Imprisonment as Measures to Punish Sexual Crimes against Children, p.1.

${ }^{15}$ See Article 7 of Law Number 12 Year 2005 concerning Ratification of the International Convenant on Civil and Political Rights (referred
} 
manipulation of his body. Puteri, et al even opined that castration as a criminal punishment truly may limit the recurrence of the criminal sexual acts but on the other hand, it makes the offenders more aggressive because sexual memory still lingers in their minds, thus it may lead to commission of a new crime. Hence, castration will fail the ultimate purpose of reducing sexual recidivities. In addition, while examining the relationship between castration as a form of punishment and the principles of sexual and reproductive rights, it is crystal clear that reproductive rights cannot be downplayed, and the state cannot impose a sanction that makes someone lose their sexual and reproductive rights. ${ }^{1}$

\subsection{Castration as Human Rights Violation of a Convict}

The first consideration is, does a convict still enjoy human rights under the law? A convict, especially if given custodian sentence, becomes an inmate. An inmate is denied some basic rights as a result of the custodian sentence passed on him or her by the court. ${ }^{2}$ Some of these rights are the rights to personal liberty and freedom of movement of the inmates as guaranteed under Sections 35 and 41 of the Constitution of the Federal Republic of Nigeria, 1999 (As Amended). However, a conviction of death sentence is an exception to the right to life. ${ }^{3}$

Meanwhile, does a convict totally lose his rights as a human being upon been convicted of the alleged offence by the court? The answer to this is in the negative. A convict, even if serving his term of sentence, does not absolutely lose his rights as a human being, he or she still enjoys basic inalienable rights, naturally given and protected in the letters and spirit of the law. ${ }^{4}$ Even from decisions of courts on the right of convicts, the Court of Appeal of Nigeria shed light on this issue of whether a convict still has a protectable right under the law. The court in Peter Nemi v. Attorney General of Lagos State \& Ors ${ }^{5}$ held that prisoners still have their rights intact, except those deprived by law, and even a condemned criminal awaiting execution still maintains his rights until properly executed by the due process of law.

More so, a person convicted of an offence still has the right not to be treated with cruelty. The United States court in Hudson v. McMillian ${ }^{6}$ ruled that any act, treatment or punishment applied maliciously and sadistically for the very purpose of causing harm amounts to cruel treatment. Also in Gregg v. Georgia, ${ }^{7}$ the court interpreted the phrase "cruel and unusual punishments" to include those punishments that were unnecessary and wanton infliction of pain" or grossly out of proportion with the severity of the crime.

Generally, criminal sentence is often accompanied by sanctions on the convict as a legal consequence of the criminal act. These sanctions attempt to create justice and balance for both the convict and the victims. ${ }^{8}$ However, castration as a form of punishment amounts to a violation of human rights, especially the right to reproduce. ${ }^{9}$ The right to sexual and reproductive health is an offshoot of the broad human rights, which is basic, fundamental and inherent for all human beings. These rights are absolute, universal and does not need permission to enjoy by all individuals. ${ }^{10}$ Castration disrupts reproductive organ function in the offender, more so, it will cause more serious damaging effects that are difficult to predict. ${ }^{11}$ The purport of the foregoing is that, every citizen of Nigeria is generally entitled to his right to human dignity and freedom from torture and degrading treatment.

Castration is subjecting a convict to an inhumane treatment and infringing on his right to human dignity. Section 34(1)(a) of the Constitution of the Federal Republic of Nigeria, 1999 (As amended) provides for the dignity of human person;

"Every individual is entitled to respect for the dignity of his person, and accordingly-

(a.) no person shall be subject to torture or to inhuman or degrading treatment;"

This provision is without derogations, restrictions or exceptions. It is an absolute provision available to every individual and no person, under any condition shall be subject to torture, inhuman or degrading treatment. This is notwithstanding whether such individual is a suspect, accused person or convict. It is therefore apt to conclude that every Nigerian citizen is entitled to his constitutional rights to human dignity and no citizen should

as the Law on Political Rights), Article 5 of the Universal Declaration of Human Rights (UDHR),

${ }^{1}$ Dina Silvia Putri, et al (note 16 above)

${ }^{2}$ Marcus Ayodeji Araromi, 'Prisoner's Rights under the Nigerian Law: Legal Pathways to Progressive Realisation and Protection' (2015)

vol6(1) ABUAD Journal of Sustainable Development Law and Policy 1

${ }^{3}$ See Section 33 of the Constitution of the Federal Republic of Nigeria, 1999 (As Amended)

${ }^{4}$ R. George, 'Natural Law' (2008) 31(1) Harvard Journal of Law and Public Policy 171

5 (1996) 6 NWLR (PT.452) 42

${ }^{6}$ (1992) 503 U.S $1,6,7$

7 (1976) 428 U.S. 153,173

${ }^{8}$ Sudewo F. A. and Abdurrachman H. 'The Use of Castration Punishment Toward Perpetrators of Sexual Violence in Indonesia, Atlantis Press' (2019) vol. 429 Advances in Social Science, Education and Humanities Research pp165-170

${ }^{9}$ Heathcote L. E. 'Chemical Castration in Indonesia: Limiting an Absolute Human Right' (2020) vol. 3(2) The Indonesian Journal of Southeast Asian Studies p 205

${ }^{10}$ WHO, 'Defining Sexual Health' (2010) [web log post]. Retrieved from

https://www.who.int/reproductivehealth/topics/sexual_health/sh_definitions/en/CEPALO

${ }^{11}$ See Zhuang J. 'Chemical Castration: International Experience and Chinese Path to Control Pedophilia Crimes' (2018) vol. 8(8) Advances in Applied Sociology pp. 575-597 
be made to undergo any form of torture or inhuman treatment.

Furthermore, the African Charter on Human and People's Rights (Ratification and Enforcement) Act clearly provides in Article 5 that:

"All forms of exploitation and degradation of man particularly slavery, slave trade, torture, cruel, inhuman of degrading punishment and treatment shall be prohibited."

The combine effect of these provisions shows that torture or inhuman treatment has no place in the Nigerian human rights jurisprudence, and from the definition of castration earlier examined, the act amounts to cruelty, torture and inhuman treatment.

More so, the Nigerian Anti-Torture Act, 2017 is a law specifically enacted in Nigeria to penalise every form of inhumane treatment. Section 2(1)(a)(b)(c) and (2)(a)(ix) of the Act defines torture thus:

"Torture is deemed committed when an act by which pain or suffering, whether physical or mental, is intentionally inflicted on a person to-

a. Obtain information or a confession from him or a third person

b. Punish him for an act he or a third has committed or he is suspected of having committed; or

c. Intimidate or coerce him or a third person for any based on discrimination of any kind

(2). For the purpose of this act, torture includes

a. Physical torture which refers to such cruel inhuman or degrading treatment which causes pain, exhaustion, disability, or day function of one or more part of the body such as

(ix). Mutilation such as amputation of the essential part of the body such as genital, ears or tongue and any other part of the body.

The wordings of this statute convey a depth repulsion against torture. In fact, torture became an act of criminality by virtue of this law regardless of the individual or person inflicting the pain. Section 3(1) of the same Act provides that:

"No exceptional circumstances whatsoever, whether a state of war or a threat of war, internal political instability or any other public emergency, may be invoked as a justification for torture."

This provision, by implication, is that torture is not only illegal in Nigeria but it is prohibited and outlawed entirely, without giving room for exceptions or justifications. The court has likewise helped in defining what constitutes torture when Tur, J.C.A in AG \& COMMISSIONER OF JUSTICE, KEEBI STATE v. JOKOLO \& $O R S^{l}$ defined torture thus:

"By torture, I mean the infliction of physically founded suffering or the threat immediately to inflict it, where such infliction or threat is intended to elicit or such infliction is incidental to means adopted to elicit, matter of intelligence or forensic proof and the motive is one of military, civil or ecclesiastical interest".

More so, the ethics of the practice of castration as an alternative punishment for perpetrators of sexual crime is highly debated. The argument that castration would drastically reduce sex drive in human males but not in human females appears to be discriminatory on the male gender, and there is no scientific or statistical proof that there would be reduction in the rate of sexual offences if castration is imposed as punishment, and even if there is, one cannot quickly conclude that the reduction in the sexual crime rate is solely due to the imposed punishment of castration. ${ }^{2}$

\subsection{Is Kaduna State Law on Castration Constitutional?}

The governor of Kaduna State, Malam El-Rufai, assented the amended the state's Penal Code Law on 11th September 2020, the new law has come into effect in Kaduna State. By the provisions of the new law, stiffer punishments were introduced especially for the offence of rape, unlike the initial law which provided for a maximum penalty of 21years imprisonment and life imprisonment for the rape of an adult and a child respectively. For the avoidance of doubt, Section 258 of the Kaduna State Penal Code (Amendment) Law 2020 provides thus:

"Whoever commits rape of a child below the age of fourteen (14) years shall on conviction, be punished with Surgical Castration and death; whoever has sexual intercourse with a male child below the age of fourteen years shall be punished with surgical castration and death; where a female adult is convicted for the offence of rape of a child, the Court shall punish the accused with Bilateral Salpingectomy and death; where the victim is above fourteen years, the Court shall on conviction sentence the accused with a punishment of surgical castration and life imprisonment; where the convict is a child, the Court shall order as appropriate under the Children and Young Person Law Cap 26 Laws of Kaduna State 1991; where the victim is a child, the Court shall in addition to the conviction, order that the convict be listed in the Sex Offenders Register to be published by the Attorney General; where the Court is trying the offence of rape involving a child below the age of fourteen years, corroboration of a medical report shall be necessary."

\footnotetext{
${ }^{1}$ (2006)11 NWLR (PT.1152)394

${ }^{2}$ Tobi Awodipe et al "Rape: Crossfire Over Castration Law" Guardian 26 September, 2020
} 
It is crystal clear from this law that castration is provided as a punishment for convicted rape offenders. The question that however comes to mind is, is this enactment in the spirit or with recourse to Section 34(1)(a) of the Constitution of the Federal Republic of Nigeria, 1999 (As Amended) which explicitly states that:

"no person shall be subject to torture or to inhuman or degrading treatment;"

Should there be a debate on constitutional supremacy over the recently enacted Kaduna state law? I think no. But for the avoidance of doubt, Section 1(3) of the Constitution of the Constitution of the Federal Republic of Nigeria, 1999 (As Amended) provides that:

"If any other law is inconsistent with the provisions of this Constitution, this Constitution shall prevail, and that other law shall, to the extent of the inconsistency, be void."

And Section 1(1) of the same Constitution provides that:

"This Constitution is supreme and its provisions shall have binding force on all authorities and persons throughout the Federal Republic of Nigeria"

From case law, Onnoghen JSC, in ADEKOYE \& ORS. v. NIGERIAN SECURITY PRINTING MINTING COMPANY LTD ${ }^{1}$ remarked that;

"We all know and in fact it is long settled that the provisions of the Constitution are supreme over any other provisions, law or Act of the National Assembly."

Denton-West JCA in TIMOTHY v. OFORKA, ${ }^{2}$ stated that;

"No law or custom that stands in the way of the constitution should be allowed to stand tall, no matter the circumstances".

In view of the stated constitutional provisions and judicial decisions, the fate of the new Kaduna state law is determined already. Castration of convicted offenders of rape under the new law is apparently inconsistent with the Nigerian Constitution and other appraised enacted laws of the National Assembly. It is therefore unconstitutional to permit the new Kaduna state law on castration to take effect.

\subsection{Conclusion}

This article has examined castration as a punishment for the offence of rape, both from criminal law and human rights perspectives. The research further attempts to answer the question of whether castration as a form of criminal sentence falls within the goals of penology. More so, the constitutionality of the the Kaduna State Penal Code (Amendment) Law 2020, particularly Section 258 of the law is likewise examined in this article. The research concludes that the introduction of castration as a punishment for rape in Kaduna State of Nigeria will rather create more legal crisis and human rights debate in the country, rather than curbing the crime of rape. The burden of proving the offence becomes stiffer and heavier considering the punishment involved, more so, just like capital punishment have been condemned and even outlawed in some countries, castration as a form of criminal punishment would also suffer the same fate for being uncivilised, inhuman and archaic.

\footnotetext{
${ }^{1}$ (2009)5 NWLR (Pt.1134)322 SC

${ }^{2}$ (2008)9 NWLR (Pt. 1091)
} 